DOI:

UDC 51-74

Y.M. Golovko, Candidate of Physics and Mathematics Sciences, Associate Professor, yngolovko@gmail.com

D.V. Klymenko, Candidate of Technical Sciences, Associate Professor, dinklimspring@gmail.com O.O. Sdvyzhkova, Doctor of Technical Sciences, Professor, sdvyzhkova@gmail.com NTU Dnipro Polytechnic, Dnipro

\title{
PROBABILITY MODEL FOR THE ERROR ESTIMATION AT SEISMIC-ACOUSTIC FORECAST WHILE COAL MINING
}

Seismic-acoustic method is widely used currently to predict rock bursts and outbursts in coal mines. To improve this method the two prognostic criteria model is developed to avoid the forecast errors. The proposed mathematical model provides decreasing the probability of type I errors ("false positive") without significant growth of type II errors ("false negative"). The probabilistic model proposed takes into consideration a time parameter as well.

Keywords: probability model; seismic-acoustic method; outburst forecast.

На даний час широко застосовується сейсмоакустичний метод для прогнозування гірських ударів і викидів гірських порід у вугільних шахтах. Для вдосконалення ивого методу розроблено модель з двома прогностичними критеріями, щоб уникнути помилок прогнозу. Запропонована математична модель передбачає зменшення ймовірності помилок I роду ("помилково позитивних") без істотного зростання помилок II роду ("помилково негативних") та враховує часовий параметр.

Ключові слова: ймовірнісна модель; сейсмоакустичний метод; прогноз викидів.

\section{Formulation of the problem}

The study of gas-dynamic phenomena mechanism in mines [1] is one of the key tasks associated with the coal and gas outburst prediction.

Seismic-acoustic method is widely used currently to predict the rock bursts and outbursts in coal mines. Nevertheless, the average level of the method reliability is $60-70 \%$ [2]. The probability of type II errors ("false negative") at predicting is about $3 \%$ [3]. But the availability of type I errors ("false positive") can be significant [5]. The probability of such error occurrence should be decreased, but at the same time increasing the type II errors ("false negative") must be excluded.

\section{Analysis of recent investigations and publications}

The outburst forecast at coal mining based on acoustic signals involves a hazard index developed in [5]:

$$
K_{B}=\frac{A_{B}}{A_{H}},
$$

where $A_{B}$ is an amplitude of high-frequency component in acoustic signal spectrum recorded in the rock mass while mining operations, $A_{H}$ is an amplitude of the low-frequency component in this spectrum. To improve the forecast technics the prognostic model has been developed by involving additional index [6]:

$$
K_{S}=\frac{S}{S},
$$

where $S_{6}$ is the spectrum area corresponding to the high-frequency component, $S$ is a general area of the amplitude-frequency spectrum. Values $S_{B}$ and $S$ can be determined by spectral estimation of signals generated by rock-destruction mechanisms: 


$$
S=\Delta \vartheta \cdot \sum_{i=0}^{i \max } A_{i}, \quad S_{B}=\Delta \vartheta \cdot \sum_{i: 700<\vartheta<1250} A_{i},
$$

where $A_{i}, i=\overline{0, i \max }$ are the amplitude magnitude, $\Delta \vartheta$ is the frequency step of the considered spectrum area. The amplitude spectrum can be estimated by the fast Fourier transformation [10].

The critical value of the prognostic index $K_{b}$ should be determined and adjusted in accordance with the appendix P.8 [4] individually for different types of excavations. The critical value of the prognostic index $K_{S}$ alters obviously within the range [0,1] and should be estimated based on practical observations.

Respectively the criteria should be held to identify the hazard situation:

$$
K_{B}=\frac{A_{B}}{A_{H}} \geq K_{B}^{*}
$$

for some interval of time $\Delta t$ and

$$
K_{S}=\frac{B}{S} \geq K_{S}^{*},
$$

where $K_{B}^{*}$ is the critical value of the prognostic index $K_{B}, K_{S}^{*}$ is the critical value of the prognostic index $K_{S}$. The criterion (2) proposed in [6] is based on studying the crack initiation under the harmonic and static stress components $[7,8]$.

The probability of type I errors ("false positive") according to the criterion (1) alters in the range from $5 \%$ to $47 \%$ [5]. That is why this criterion requires some varies to decrease the probability of these errors. That is why the new model has been developed [6] for simultaneous applying both outburst hazard criteria to improve the gas-dynamic phenomena prediction. To prove the effectiveness of the proposed model the probability of forecast errors should be estimated.

\section{Formulation of the research objective}

An algorithm should be developed using prognostic indices $K_{b}, K_{S}$ to improve the seismicacoustic method for predicting gas-dynamic phenomena in mines. That is why the proposed model in [6] should be corrected to decrease the probability of type I errors ("false positive") without increasing probability of type II errors ("false negative").

\section{Statement of the main material}

Estimating the probability of an error occurring at the outburst forecast based on acoustic signals.

While coal mining the special seismic bureau must give message «hazardous», if the criterion (1) is fulfilled during the time interval $\Delta t$ and over.

The criterion (1) can be corrected by increasing the critical value $K_{B}^{*}$ and/or by increasing the time interval $\Delta t$. These alters provide decreasing the probability of the type I errors («false positive»). But at the same time such varies obviously increase the probability of the type II errors («false negative») representing greatest hazard.

Physical interpretation of the criterion (1) is following. Gas-dynamic phenomena are associated with crack initiation identified by growing of high-frequency component of the spectrum $A_{b}$ [5]. Hence, increasing of the value $A_{b}$ means increasing the ratio (1). However, the prognostic indicator $K_{b}$ can grow as well if its denominator decreases. But decreasing of low-frequency component of the spectrum $A_{H}$ does not mean dangerous situation in rock mass [10] and does not identifies gasdynamic onset. 
This fact can be substantial reason for the type I errors («false positive») while applying the criterion (1). The criterion (2) has not this flaw because depends on the amplitude spectrum integral. The physical interpretation of the prognostic index $K_{S}$ is the ratio of the high-frequency oscillations power to the total oscillations power at given «point» of the study.

As mentioned above the two-criteria outburst model that included prognostic indicators $K_{b}$ and $K_{S}$ has been developed [6]. But the model fetches have not been founded and the introduction of a time parameter has not been done. That is why this paper focused on developing the probability models of occurring both type errors («false positive» and «false negative») while acoustic analysis.

To identify different level of hazard we introduce two notions:

- possible hazardous rock state/possible not hazardous rock state,

- hazardous rock state/not hazardous rock state.

First notion means fulfillment/non-fulfillment of criteria (1) and (2), second notion means making decision based on the observations over a time period $\Delta T$.

Additionally, following notations should be involved:

$H_{0}=\{$ not hazardous rock state $\}$ is a primary hypothesis;

$\overline{H_{0}}=\{$ hazardous rock state $\}$ is an alternative hypothesis.

Such events should be discussed:

$A_{i}=\{$ the signal is «possible not hazardous rock state» according to the $i$-th criterion $\}$;

$\overline{A_{i}}=\{$ the signal is «possible hazardous rock state» according to the $i$-th criterion $\}$;

$B=\{$ decision «not hazardous rock state $) ;$

$\bar{B}=\{$ decision $«$ hazardous rock state $~\}$;

$H_{0} \bar{A}_{i}=\{$ type I errors according to the $i$-th criterion («false positive») $\}$;

$\overline{H_{0}} A_{i}=\{$ type II errors according to the $i$-th criterion («false negative») $\}$;

$H_{0} \bar{B}=\{$ decision has a type I error $\}$;

$\overline{H_{0}} B=\{$ decision has a type II error $\}$.

$\alpha_{i}=P_{H_{0}}\left(\overline{A_{i}}\right)$ is type I error probability according to the $i$-th criterion;

$\beta_{i}=P_{\overline{H_{0}}}\left(A_{i}\right)$ is type II error probability according to the $i$-th criterion;

$\alpha=P_{H_{0}}(\bar{B})$ is type I error probability of made decision;

$\beta=P_{\overline{H_{0}}}(B)$ is type II error probability of made decision.

The type I and II errors probabilities are determined by the criterion function:

$$
B=f\left(\varphi_{1}, \varphi_{2}\right),
$$

where $\varphi_{1}$ is a function with respect of prognostic indicator $K_{6}, \varphi_{2}$ is a function with respect of prognostic indicator $K_{S}$.

Consider two possible variants for the decision making. First variant is following. Let the criterion function be

$$
B=A_{1} A_{2}
$$


In this case we make a decision «not hazardous rock state» when both criteria show the prediction «possible not hazardous rock state». Then opposite event looks like $\bar{B}=\overline{A_{1} A_{2}}=\overline{A_{1}}+\overline{A_{2}}$. The type I errors probability of making decision can be estimated in such way:

$$
\begin{aligned}
\alpha=P_{H_{0}}(\bar{B}) & =P_{H_{0}}\left(\overline{A_{1}}+\overline{A_{2}}\right)=P_{H_{0}}\left(\overline{A_{1}}\right)+P_{H_{0}}\left(\overline{A_{2}}\right)-P_{H_{0}}\left(\overline{A_{1}}\right) P_{H_{0}} \overline{A_{1}}\left(\overline{A_{2}}\right)= \\
& =\alpha_{1}+\alpha_{2}-\alpha_{1} \alpha_{2(1)}=\alpha_{1}+\alpha_{2} \cdot\left(1-\alpha_{2(1)} \cdot \frac{\alpha_{1}}{\alpha_{2}}\right)
\end{aligned}
$$

and the type II errors probability looks like:

$$
\beta=P_{\overline{H_{0}}}(B)=P_{\overline{H_{0}}}\left(A_{1} A_{2}\right)=P_{\overline{H_{0}}}\left(A_{1}\right) P_{\overline{H_{0}}} A_{1}\left(A_{2}\right)=\beta_{1} \beta_{2(1)},
$$

where $\alpha_{2(1)}$ and $\beta_{2(1)}$ are the type I and II errors probabilities according to the criterion (2) respectively under condition that the type I errors also has occurred according to the criterion (1).

If the errors are independent according to different criteria, then $\alpha_{2(1)}=\alpha_{2}$ and $\beta_{2(1)}=\beta_{2}$. However, this situation should be considered as extreme one because the obvious dependence between events $A_{1}$ and $A_{2}$ exists. That is why we suppose the probabilities satisfy the inequality $\alpha_{2(1)}>\alpha_{2}$ and $\beta_{2(1)}>\beta_{2}$.

It can be seen from the expression (4) that the type I error («false positive») probability increases, but at the same time the type II error («false negative») probability decreases according to the expression (5). The result obtained goes against the constitutive idea of the model that aims decreasing the type I errors probability in the hazard forecast.

Consider second possible variant for the decision making. Let the criterion function be

$$
B=A_{1}+A_{2} \text {. }
$$

In this case we decide «not hazardous rock state» when at least one of the criteria shows the prediction «possible not hazardous rock state».

Then opposite event is $\bar{B}=\overline{A_{1}+A_{2}}=\overline{A_{1}} \overline{A_{2}}$ and

$$
\begin{gathered}
\alpha=P_{H_{0}}(\bar{B})=P_{H_{0}}\left(\overline{A_{1}} \overline{A_{2}}\right)=P_{H_{0}}\left(\overline{A_{1}}\right) \cdot P_{H_{0} \overline{A_{1}}}\left(\overline{A_{2}}\right)=\alpha_{1} \cdot \alpha_{2(1)}, \\
\beta=P_{\overline{H_{0}}}(B)=P_{\overline{H_{0}}}\left(A_{1}+A_{2}\right)=P_{\overline{H_{0}}}\left(A_{1}\right)+P_{\overline{H_{0}}}\left(A_{2}\right)-P_{\overline{H_{0}}}\left(A_{1}\right) P_{\overline{H_{0}} A_{1}}\left(A_{2}\right)= \\
=\beta_{1}+\beta_{2}-\beta_{1} \cdot \beta_{2(1)}=\beta_{1}+\beta_{2} \cdot\left(1-\beta_{2(1)} \cdot \frac{\beta_{1}}{\beta_{2}}\right) .
\end{gathered}
$$

Obviously, the type I error («false positive») probability decreases according to the equation (7). At the same time the type II error («false negative») probability increases according to the equation (8) because of summarizing quantities $\beta_{1}, \beta_{2}$. However according to experimental data [5] the probabilities $\beta_{1}, \beta_{2}, \beta_{2(1)}$ are sufficiently small. That is why the type II error probability growth in the equation (8) is not significant. Obtained result provides decreasing the type I error probability in hazard forecast.

Thus, the variant of decision making according the model (6) meets the requirements of prediction «not hazardous rock state». 
It should be noted that making decision «not hazardous rock state» according to the criterion (2) is not sufficiently confirmed experimentally. That is why it should be entered a twice time interval in criterion (1) to check the criterion (2) fulfillment. As a result the prediction «not hazardous rock state» looks like:

$$
\left.\left.\left(A_{1}+A_{2}\right)\right|_{t \in\left[t_{0}, t_{0}+\Delta T\right]} \cdot A_{1}\right|_{t \in\left[t_{1}, t_{1}+2 \cdot \Delta T\right]},
$$

where $t_{0}, t_{1}$ are arbitrary time moments in the interval investigated.

Then the prediction «not hazardous rock state» according to the developed model (9) can be represented:

$$
\left.\left[\left(K_{B}<K_{B}^{*}\right)+\left(K_{S}<K_{S}^{*}\right)\right]_{t \in\left[t_{0}, t_{0}+\Delta T\right]} \cdot\left(K_{B}<K_{B}^{*}\right)\right|_{t \in\left[t_{1}, t_{1}+2 \cdot \Delta T\right]} .
$$

The opposite prediction «hazardous rock state» according to the developed model (9) looks like:

$$
\left[\left(K_{B}>K_{B}^{*}\right) \cdot\left(K_{S}>K_{S}^{*}\right)\right]_{t \in\left[t_{0}, t_{0}+\Delta T\right]}+\left.\left(K_{B}>K_{B}^{*}\right)\right|_{t \in\left[t_{1}, t_{1}+2 \cdot \Delta T\right]}
$$

The numerical estimation of the type I errors probabilities has been made involving statistical data accumulated at different regions of coal mining [5]. The type I errors probabilities decreased up to $1,5-2,1$ time approximately on making decision «not hazardous rock state» (10). Let us prove it.

The type I error probability while using only the criterion (1) is $0,05-0,47$ for various coal mines according to experimental data, thus, $\alpha_{1} \in[0,05 ; 0,47]$. Then the type I error probability in the criterion (2) can be as follows: 1) $\left.\alpha_{2} \leq 0,47,2\right) \alpha_{2}>0,47$.

The variant «not hazardous rock state» according to the model (6) provides the type I error probability decreasing in $\frac{1}{\alpha_{2(1)}}$ time according to expression (7), where $\alpha_{2(1)}$ is the type I error probability in the criterion (2) respectively under the condition that the type I error also has occurred according to the criterion (1).

If $\alpha_{2} \leq 0,47$ then the "conditional" probability of the type I error probability $\alpha_{2(1)}$ can also take values that are less, equal or greater than 0,47 . Let us discuss cases $\alpha_{2(1)} \leq 0,47$ and $\alpha_{2(1)}>0,47$. The probability of decreasing the type I error according to the scenario (6) is estimated by the following inequalities: $\frac{1}{\alpha_{2(1)}} \geq 2,13$ and $1<\frac{1}{\alpha_{2(1)}}<2,13$ respectively.

Let us discuss another case, when the type I error probability in the criterion (2) is $\alpha_{2}>0,47$. Making similar reasoning, we get the same inequalities $\frac{1}{\alpha_{2(1)}} \geq 2,13$ and $1<\frac{1}{\alpha_{2(1)}}<2,13$.

Hence, without loss of generality, we consider that type I error probability while decisionmaking according to the model (6) decreases up to 1,5-2,1 time.

\section{Conclusions and Path Forward}

New two-criteria technics has been developed to forecast the gas-dynamic phenomena based on seismic-acoustic signals in rock mass. The probability of the forecast error has been estimated based on simulating different probability scenario. Due to probability estimation the best combination of criteria has been chosen. We proved that the prediction «not hazardous rock state» according to the developed criterion (10) has the probability of a type I error less than prediction according to the criterion (1). 
The proposed two-criteria prediction technics with identifying situations «not hazardous rock state» according to (10) and «hazardous rock state» according to (11) has been incorporated in the hardware and software of seismic-acoustic complex at coal mines "Toretska", "Tsentralna" (Ukraine, Donetska region, Toretsk).

\section{Acknowledgement}

We are very grateful the stuff of the Mining Enterprise "Toretskugol" for the help in statistical data gathering and testing the hardware-software acoustic complex.

\section{References}

[1] Olovyannyi, A.G. (2012). Meckanika gornykh porod. Modelirovaniye razrushenyi: monografiya. St. Petersburg: KOSTA. 279 p.

[2] Deglin, B.M. (2004). Blesk i nishcheta prognozyrovaniya. Ugol' Ukrainy, 10 (574). http://uran.donntu.org/ masters/2011/igg/velikoivanenko/library/stat2.htm

[3] Nikiforov, A.V. (2013). Kontseptsiya bezopasnogo vedeniya gornykh robot na plastskh, sklonnykh k gazodinamicheskim yavleniyam. Ways and means of creating safe and healthy working conditions in coal mines. Collection of sci. works MakNII. 2 (32), 44-57.

[4] Ukraine coal industry standard SOU 10.100174088.011-2005 (2005). Pravila vedennya girnychih robit na plastah, shilnyh do gazodinamicynyh yavisch (rozdily 6.3.4, 6.3.5). Kiev: Ministerstvo uholnoi promyshlennosti Ukrainy. 34-38.

[5] Maslennikov, E. (2001). Obosnovaniye parametrov prognoza vybrosoopasnosti v ugolnykh shakhtakh na osnove analiza akusticheskogo signala. Ph.D. NMU.

[6] Golovko, Yu., Sdvyzhkova, E., \& Klymenko, D. (2017). Skachkoobraznoe izmenenie dliny kriticheskoy treshchiny pri kolebatelnom vozdeystvii kak factor vozniknoveniya dinamicheskoho yavleniya. In Forum hirnykiv (pp. 135-144) Dnipropetrovsk: Natsionalnyi hirnychyi universytet.

[7] Sdvyzhkova, O., Golovko, Yu., Dubytska, M., \& Klymenko, D. (2016). Studying a crack initiation in terms of elastic oscillations in stress strain rock mass. Mining of Mineral Deposits, 10 (2), 72-77. http://dx.doi.org/10.15407/mining 10.02.072

[8] Golovko, Yu., Sdvyzhkova, E., \& Klymenko, D. (2017). Generalized criterion of crack initiation in terms of oscillations in stress strain rock mass. Bulletin KrNU by M. Ostrogradsky, 1(102), 41-49.

[9] Golovko, Yu. (2017). Spectral parameters estimations of seismoacoustic signals for the current predict of gas-dynamic phenomena in mines. Heotekhnichna Meckanika, 134, 141-154.

[10] Klymenko, D. (2018). Zakonomernosti proyaviv i seismoakusticheskiy prohnoz hazodinamichnyh yavishch pri vidpratsuvanni vuhilnyh plastiv. Ph.D. National TU Dnipro Polytechnic.

\section{ЙМОВІРНІСНА МОДЕЛЬ ОЦІНКИ ПОМИЛОК СЕЙСМОАКУСТИЧНОГО ПРОГНОЗУ ПРИ ВИДОБУТКУ ВУГІЛЛЯ \\ Головко Ю.М., Клименко Д.В., Сдвижкова О.О.}

\section{Реферат}

На даний час для прогнозування вибухів гірських порід у вугільних шахтах широко застосовується сейсмоакустичний метод. Тим не менше, середній рівень надійності цього методу становить близько 60-70 \%. Імовірність помилок II роду («помилково негативні») при прогнозуванні становить близько 3 \%. Але наявність помилок I роду («помилково позитивні») може бути значним. Ймовірність виникнення таких помилок слід зменшити, але в той же час збільшуються помилки II роду («помилково негативні»), що слід виключити.

Для вдосконалення техніки прогнозу була розроблена прогностична модель, що включає два показники: показник

$$
K_{B}=\frac{A_{B}}{A_{H}},
$$


де $A_{B}$ - високочастотна амплітуда в спектрі акустичного сигналу, $A_{H}-$ низькочастотна амплітуда в спектрі акустичного сигналу, та показник

$$
K_{S}=\frac{S_{B}}{S},
$$

де $S_{6}$ є площею спектра, що відповідає високочастотній компоненті спектру акустичного сигналу, $S$ є загальна площа амплітудно-частотного спектра сигналу. Відповідно, слід визначити два критерії для виявлення небезпечної ситуації: $K_{b}=\frac{A_{B}}{A_{H}} \geq K_{\theta}^{*}$ у проміжок часу $\Delta t$ і більше, та $K_{S}=\frac{S_{B}}{S} \geq K_{S}^{*}$, де $K_{B}^{*}-$ критичне значення прогностичного показника $K_{B}, K_{S}^{*} \epsilon$ критичним значенням прогностичного показника $K_{S}$.

Віддається перевага моделі з двома критеріями, що забезпечує зменшення ймовірності помилок першого роду («помилково позитивні»).

Запропоновані критерії (моделі прийняття рішень) застосовані при розробці шахтного сейсмоакустичного апаратно-програмного комплексу.

\section{Література}

1. Оловянный А.Г. Механика горных пород. Моделирование разрушений: монография. СПб: ООО «Издательско-полиграфическая компания «КОСТА», 2012. 280 с.

2. Блеск и нищета прогнозирования [Електронний ресурс]/ Деглин Б.М. Вугілля України, №10(574), 2004. Режим доступу:

http://uran.donntu.org/ masters/2011/igg/velikoivanenko/library/stat2.htm (дата звернення 29.09.2019).

3. Никифоров А.В. Концепция безопасного ведения горных работ на пластах, склонных к газодинамическим явлениям. Способы и средства создания безопасных и здоровых условий труда в угольных шахтах: зб. наук. пр. Макіївка: МакНДІ, 2013. Вип. 2(32). С. 44-57.

4. СОУ 10.1.00174088.011-2005. Правила ведення гірничих робіт на пластах, схильних до газодинамічних явищ (розділи 6.3.4, 6.3.5.). [Чинний від 2005-12-30]. К.: Мінвуглепром України, 2005. C. 34-38.

5. Масленников Е.В. Обоснование параметров прогноза выбросоопасности в угольных шахтах на основе анализа акустического сигнала: дис. ... канд. тех. наук: 05.15.11/ Днепропетровск: НГУ, 2001. $140 \mathrm{c}$.

6. Головко Ю.М., Сдвижкова О.О., Клименко Д.В. Стрибкоподібна зміна довжини критичної тріщини при коливальному впливі як фактор виникнення динамічного явища. Форум гірників: Матеріали Міжнародної науково-технічної конференції, м. Дніпро, 4-7 жовтня 2017 p. Дніпро: НГУ, 2017. С. 135-144.

7. Sdvyzhkova O., Golovko Yu., Dubytska M., Klymenko D. Studying a crack initiation in terms of elastic oscillations in stress strain rock mass. Mining of Mineral Deposits. Dnipro: NMU, 2016. Vol. 10, Issue 2. Р. 72-77. Режим доступу: http://dx.doi.org/10.15407/mining10.02.072 (дата звернення 29.09.2019).

8. Головко Ю.М., Сдвижкова О.О., Клименко Д.В. Узагальнена умова страгування тріщини, що ініційоване коливаннями в породному напружено-деформованому середовищі. Вісник КрНУ імені Михайла Остроградського. Кременчук, 2017. Вип. 1 (102). С. 41-49.

9. Головко Ю.Н. Оценка спектральных параметров сейсмоакустических сигналов при текущем прогнозе газодинамических явлений в шахтах. Геотехническая механика: Межведомственный сборник научных трудов. Дніпро: 2017. Вип. 134. С. 141-154.

10.Клименко Д.В. Закономірності проявів і сейсмоакустичний прогноз газодинамічних явищ при відпрацюванні вугільних пластів: дис. ... канд. тех. наук: 05.15.09/Дніпро: НТУ «Дніпровська політехніка», 2018. 184 с. 